\title{
Analisis Dan Desain Aplikasi Pendaftaran Mahasiswa Baru Berbasis SMS, Studi Kasus: Asmi Santa Maria Yogyakarta
}

\author{
Petrus $^{1}$, Suyoto ${ }^{2}$, Thomas Suselo ${ }^{3}$ \\ Program Studi Manajemen Perusahaan, Asmi Santa Maria Yogyakarta \\ Jl. Bener 14, Tegalrejo, Yogyakarta 55243, Indonesia \\ Email: supitz@yahoo.co.id
}

\begin{abstract}
Analysis And Design of SMS-Based New Student Registration Application, Case Study: Asmi Santa Maria Yogyakarta. This study aims to analyze and designing new mahasisaw registration applications based on SMS in Asmi Santa Maria Jogjakarta. Through analysis and design of these authors provide suggestions for the agency intends to implement the OAU-Based Applications SMS (APMB-SMS). Applications that are designed to provide modules that facilitate the management of student enrollment that includes a wave of new registration, course selection, data registries, and reports of new student enrollment. Application of the proposed new student enrollment based on SMS with a structured approach.
\end{abstract}

Keywords: SMS, Registration Application, Structured Approach

Intisari. Penelitian ini bertujuan untuk menganalisis dan medesain aplikasi pendaftaran mahasisaw baru berbasis SMS di ASMI Santa Maria Yogyakarta. Melalui analisis dan desain ini penulis bermaksud memberikan usulan bagi lembaga untuk mengimplementasikan Aplikasi Pendaftaran Mahasiswa Baru Berbasis SMS (APMB-SMS). Aplikasi yang dirancang menyediakan modul-modul yang memudahkan pengelolaan pendaftaran mahasiswa baru yang meliputi gelombang pendaftaran, pilihan program studi, data pendaftar, dan laporan pendaftaran mahasiswa baru. Aplikasi pendaftaran mahasiswa baru yang diusulkan berbasis SMS dengan pendekatan terstruktur.

Kata Kunci: SMS, Aplikasi pendaftaran, pendekatan terstruktur.

\section{Pendahuluan}

\subsection{Latar Belakang}

Perkembangan teknologi informasi telah merambah ke berbagai bidang kehidupan manusia, tak terkecuali bidang pendidikan Perguruan Tinggi yang senantiasa mengadaptasi perkembangan teknologi tersebut. Kini pendidikan tinggi memanfaatkan teknologi tersebut untuk membantu aktifitas akademik maupun administrasi pendidikan.

ASMI Santa Maria Yogyakarta merupakan salah satu Perguruan Tinggi Vokasi yang sampai saat ini sudah berusia 35 tahun masih banyak diminati oleh lulusan Sekolah Menengah Atas tidak hanya pendaftar dari Yogyakarta saja melainkan juga dari luar kota. Kampus ASMI Santa Maria Yogyakarta berlokasi di Jl. Bener 14 Tegalrejo Kota Yogyakarta memiliki lingkungan asri serta nyaman untuk belajar sehingga sampai saat ini masih memiliki jumlah mahasiswa stabil, baik dari sisi student body maupun pendaftar tiap tahunnya.

Banyaknya pendaftar hingga sekarang masih dilayani secara manual yakni dicatat dalam buku besar, kemudian baru diinput ke dalam komputer tersendiri (stand alone) untuk diolah sesuai kebutuhan seperti mencetak kartu test, pengumuman hasil test, mencetak amplop 
hasil test. Bagi pendaftar yang menggunakan layanan hot line SMS biasanya hanya mengirimkan nama dan alamat untuk kemudian ditindaklanjuti oleh Panitia PMB dengan cara ditelpon balik untuk dicatat biodata pendaftar tersebut. Pendaftar yang menggunakan cara SMS ini mencakup yang berasal dari Yogyakarta maupun yang berasal dari luar kota. Pelayanan terhadap metode pendaftaran yang ada selama ini tidak semuanya bisa ditangani dengan baik. Terkadang ada pendaftar sama yang ditelpon dua sampai tiga kali, atau bahkan ada pendaftar yang lupa ditangani. Sistem kerja seperti ini jelas akan merugikan institusi ASMI maupun calon pendaftar mahasiswa baru yang bersangkutan.

Berdasar latar belakang tersebut, penulis tertarik merancang aplikasi berbasis SMS untuk sistem penerimaan mahasiswa baru mengingat sampai sekarang teknologi SMS masih diminati oleh sebagian besar pengguna telepon seluler di nagara kita baik masyarakat kota maupun pendesaan. (Aryani. 2006) Meskipun teknologi informasi sudah berkembang semakin cepat dengan berbagai aplikasi berbasis web, namun penulis masih menggunakan teknologi berbasis SMS dengan pertimbangan sistem informasi yang ada di ASMI saat ini masih sederhana serta segmen pendaftar calon mahasiswa baru sebagaian besar tergolong ekonomi menengah ke bawah.

\subsection{Perumusan Masalah}

Berdasarkan latar belakang diatas, maka penulis merumuskan permasalahan yaitu Bagaimana menganalisis dan mendesain aplikasi pendaftaran mahasiswa baru berbasis SMS pada ASMI Santa Maria Yogyakarta?

\subsection{Batasan Masalah}

Agar pembahasan tidak melebar dari topik, maka penulis membatasi permasalahan penelitian yaitu pengembangan aplikasi dilakukan hingga tahap analisa dan perancangan aplikasi pendaftaran mahasiswa baru berbasis SMS dengan menggunakan telepon seluler sebagai fasilitas penerima dan pengirim data.

\subsection{Manfaat Penelitian}

Penelitian ini diharapkan dapat memberikan manfaat sebagai berikut. (1) Bagi ASMI Santa Maria Yogyakarta. Hasil penelitian ini dapat digunakan sebagai acuan bagi lembaga ASMI Santa Maria Yogyakarta untuk pengambilan keputusan guna penyempurnaan sistem penerimaan mahasiswa baru (PMB) yang telah ada yakni dari sistem pendaftaran secara manual baik yang datang langsung ke kampus maupun telepon dari luar kampus menjadi sistem aplikasi pendaftaran mahasiswa baru berbasis SMS. (2) Bagi pengembang sistem. Hasil evaluasi terhadap sistem dapat digunakan sebagai bahan masukan untuk membangun sistem aplikasi pendaftaran mahasiswa baru berbasis SMS. (3) Bagi lembaga sejenis. Kebutuhan lembaga sejenis akan aplikasi pendaftaran mahasiswa baru berbasis SMS sangat bervariasi dan tergantung pada kompleksitas lembaga bersangkutan. Hasil penelitian ini dapat memberikan inspirasi bagi lembaga sejenis yang bergerak di bidang layanan pendidikan untuk pengembangan aplikasi pendaftaran mahasiswa baru berbasis SMS.

\section{Tinjauan Pustaka}

Penelitian terhadap pemanfaatan teknologi SMS ini telah banyak dilakukan sebelumnya khususnya yang berkaitan dengan bidang administrasi akademik ataupun memiliki cara kerja yang mirip untuk diterapkan di bidang administrasi akademik, diantaranya adalah sebagai berikut.

Alfonsius Situmorang pada tahun 2004 melakukan penelitian tentang implementasi SMS gateway pada sistem informasi akademik. Sistem informasi ini memiliki kemampuan untuk 
memberikan informasi dari basis data, melakukan proses pendaftaran mata kuliah, akses nilai bagi mahasiswa. Bagi pengguna sistem dapat mengirimkan pengumuman secara cepat pada mahasiswa atau dosen. Informasi disajikan dalam bentuk SMS yang diterima oleh pemakai berdasarkan query identitas dan keyword yang dikirimkan oleh pemakai ke sistem informasi ini. Hasil penelitian sistem dapat berfungsi sebagaimana mestinya. Informasi selalu aktual, mahasiswa dapat mendaftar mata kuliah dan SMS Gateway menggunakan perangkat lunak yang dibangun oleh GPA Technology Australia.

Kristian Mahardanu, melakukan penelitian mengenai pengembangan aplikasi SMS Gateway untuk penerimaan program magang kerja di Jepang, studi kasus pada Disnakertrans Jawa Tengah, tahun 2007. Penelitian tersebut membangun perangkat lunak AppSS yang merupakan implementasi dari aplikasi SMS Gateway yang akan digunakan oleh Disnakertrans Jawa Tengah.

Wiesan, melakukan penelitian tentang Desain aplikasi SMS Gateway untuk sistem informasi, tahun 2008. Melalui penelitian ini dihasilkan aplikasi SMS Gateway untuk sistem informasi layanan data barang, menggunakan program Microsoft Visual basic dan program Miscrosoft Access untuk database-nya.

Nikodemus P. Simamora, melakukan penelitian tentang pembangunan aplikasi SMS Gateway layanan kesehatan Puskesmas, tahun 2009. Pada penelitian ini ingin membangun aplikasi berbasis SMS Gateway untuk menangani laporan atau keluhan serta kritik dan saran yang disampaikan oleh masyarakat lewat media SMS yang disediakan oleh instansi terkait

Sarwati Rahayu, Mahmudi melakukan penelitian mengenai perancangan program aplikasi pemesanan barang melalui SMS menggunakan Visual Basic 6.0. Maraknya penggunaan ponsel untuk berkirim SMS telah memunculkan beberapa jenis layanan berbasis SMS seperti info valas, harga saham, jadwal sarana angkutan, film bisokop, transaksi perbankan, registrasi keanggotaan, pooling SMS dan kuis melalui SMS sehingga aplikasi layanan berbasis SMS interaktif menjadi salah satu solusinya (Sarwati Rahayu, 2009)

\section{Metode Penelitian}

Pendekatan yang digunakan dalam penelitian ini adalah analisis dan desain berdasarkan struktur. Tahap perancangan dan desain APMB-SMS adalah sebagai berikut: (1) Perancangan aliran data dalam bentuk Data Flow Diagram (DFD). (2) Perancangan flowchart sistem. (3) Perancangan basis data (database). (4) Perancangan antarmuka sistem.

\section{Hasil dan Pembahasan}

\subsection{Perancangan Aliran Data}

Diagram Alir Data atau DFD (Data Flow Diagram) merupakan suatu model logika data atau proses yang dibuat untuk menggambarkan dari mana asal data dan ke mana tujuan data yang keluar dari sistem, dimana data disimpan, proses apa yang menghasilkan data tersebut dan interaksi antara data yang tersimpan dan proses yang dikenakan pada data tersebut. Sehingga dengan DFD ini bisa diketahui dimana data disimpan dan bagaimana transformasi datanya.

\subsubsection{Diagram Konteks}

Pada diagram konteks DFD gambar 1 tersebut dapat diamati bahwa entitas yang terlibat adalah administrator system dan calon mahasiswa baru. Administrator bertugas memasukkan data program studi dan gelobang tes. Calon mahasiswa akan memasukkan data pendaftaran melalui sarana SMS. Kemudian calon mahasiswa akan menerima balasan dari SMS tersebut. Proses ini akan menghasilkan daftar mahasiswa baru dan dilaporkan kepada admin dalam bentuk laporan pendaftaran dan laporan rekap pendaftaran. 


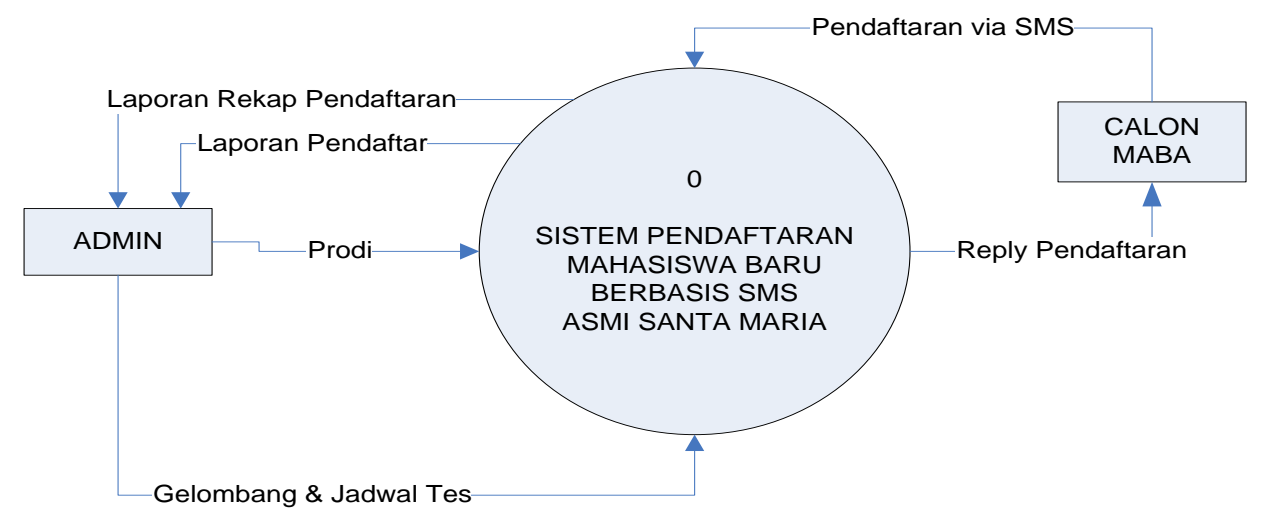

Gambar 1. Diagram Konteks DFD

\subsubsection{DFD Level 1}

DFD Level 1 diagram konteks perlu diperinci setiap sub proses di dalamnya. Dalam setiap sub proses akan terlihat proses-proses apakah yang dilakukan oleh sistem dan urutan proses-proses tersebut dalam melayani para pengguna yang terlibat.

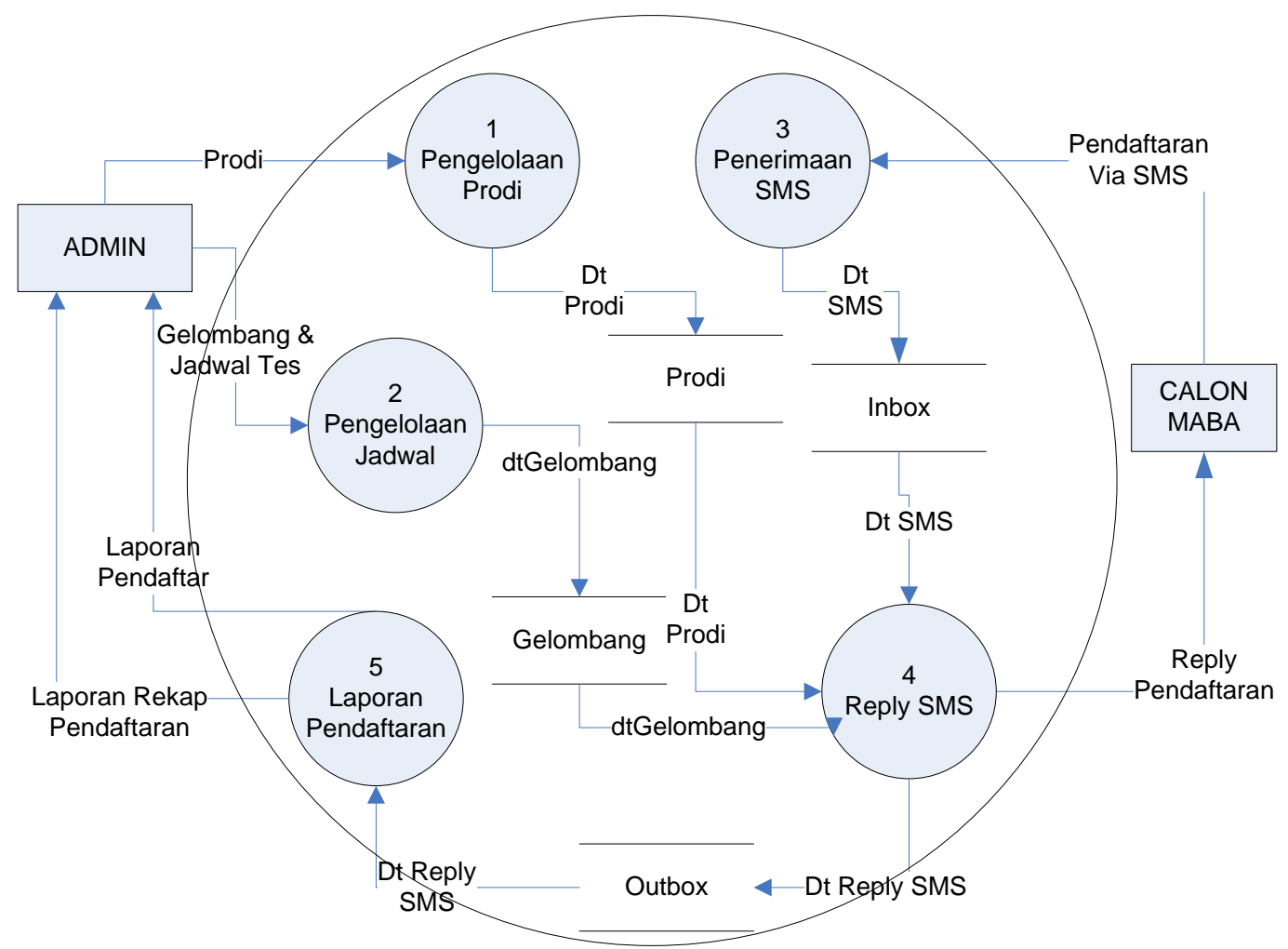

Gambar 2. DFD Level 1

Pada Gambar 2 terdapat 5 sub proses dalam sistem. Sub proses pertama adalah sub proses pengelolaan program studi. Sub proses ini berguna untuk menambah, edit dan hapus data program studi dan kemudian data disimpan dalam tabel Program studi. Sub proses kedua adalah pengelolaan jadwal. Sub proses ini akan menambah, edit dan hapus data gelombang dan test kemudian disimpan dalam tabel Gelombang. Sub proses ketiga adalah sub proses Penerimaan SMS. Sub proses ini akan menerima SMS masuk dan direkam dalam tabel Inbox. Sub proses keempat adalah proses Reply SMS. Sub proses ini akan membaca SMS dalam Inbox dan akan melakukan proses parsing terhadap SMS tersebut. Jika proses parsing menemukan kesalahan 
maka pesan balasan berupa pesan peringatan. Jika proses parsing sukses maka data calon mahasiswa pendaftar akan direkam dalam tabel Outbox, sekaligus calon mahasiswa diberi reply tanggal test. Sub proses kelima adalah proses pembuatan laporan. Laporan ada dua yaitu laporan pendaftar melalui SMS dan laporan rekap pendaftaran.

\subsection{Perancangan Flowchart Sistem}

Flowchart sistem menggambarkan alur program SMS auto respond dari sistem. Hal ini merupakan fasilitas utama dari sistem yang dibangun. Flowchart ini merupakan penjabaran sub proses Reply SMS dalam data flow diagram level 1 pada gambar 3.

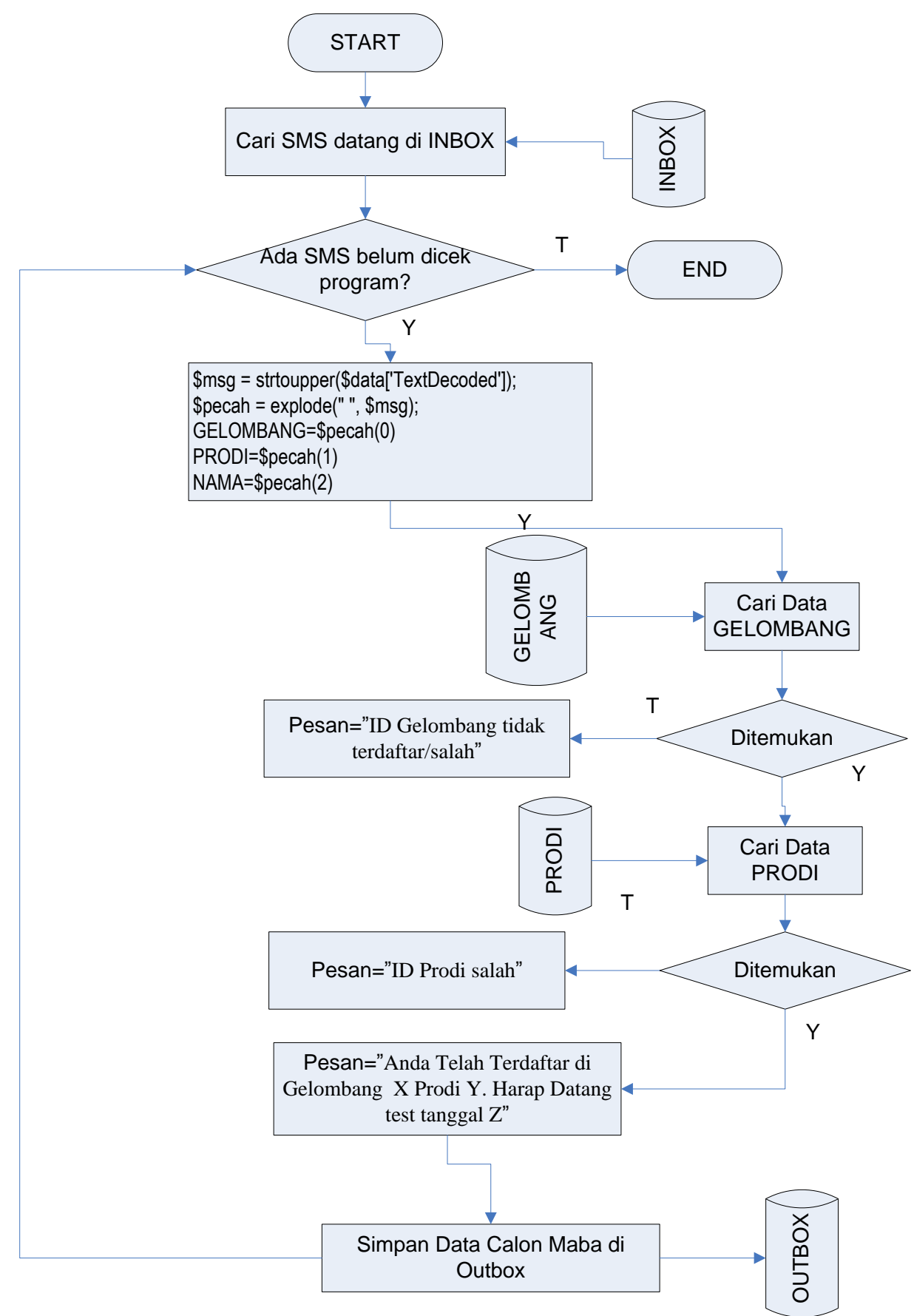

Gambar 3. Flowchart Auto Reply SMS 
Flowchart menggambarkan proses Reply SMS. Proses diawali dari pembacan tabel inbox apakah ada SMS dating. Jika ada maka SMS tersebut dibaca dan dipilah berdasarkan parameter SMS nya, yaitu gelombang, prodi, dan nama calon mahasiswa. Langkah berikutnya adalah pengecekan apakah gelombang dan prodi ada dalam daftar. Jika tidak ada maka akan mengembalikan pesan SMS berupa pesan kesalahan. Jika ada dan SMS tersebut valid maka data calon mahasiswa baru akan disimpan dalam tabel outbox. Aplikasi akan mengirimkan pesan berupa tanggal tes dan syarat pendaftaran.

\subsection{Perancangan Basis Data}

\subsubsection{Entity Relationship Diagram (ERD)}

ER-Diagram dipakai untuk merancang basis data dan menentukan hubungan antar entitas dalam kaitannya perancangan basis data.

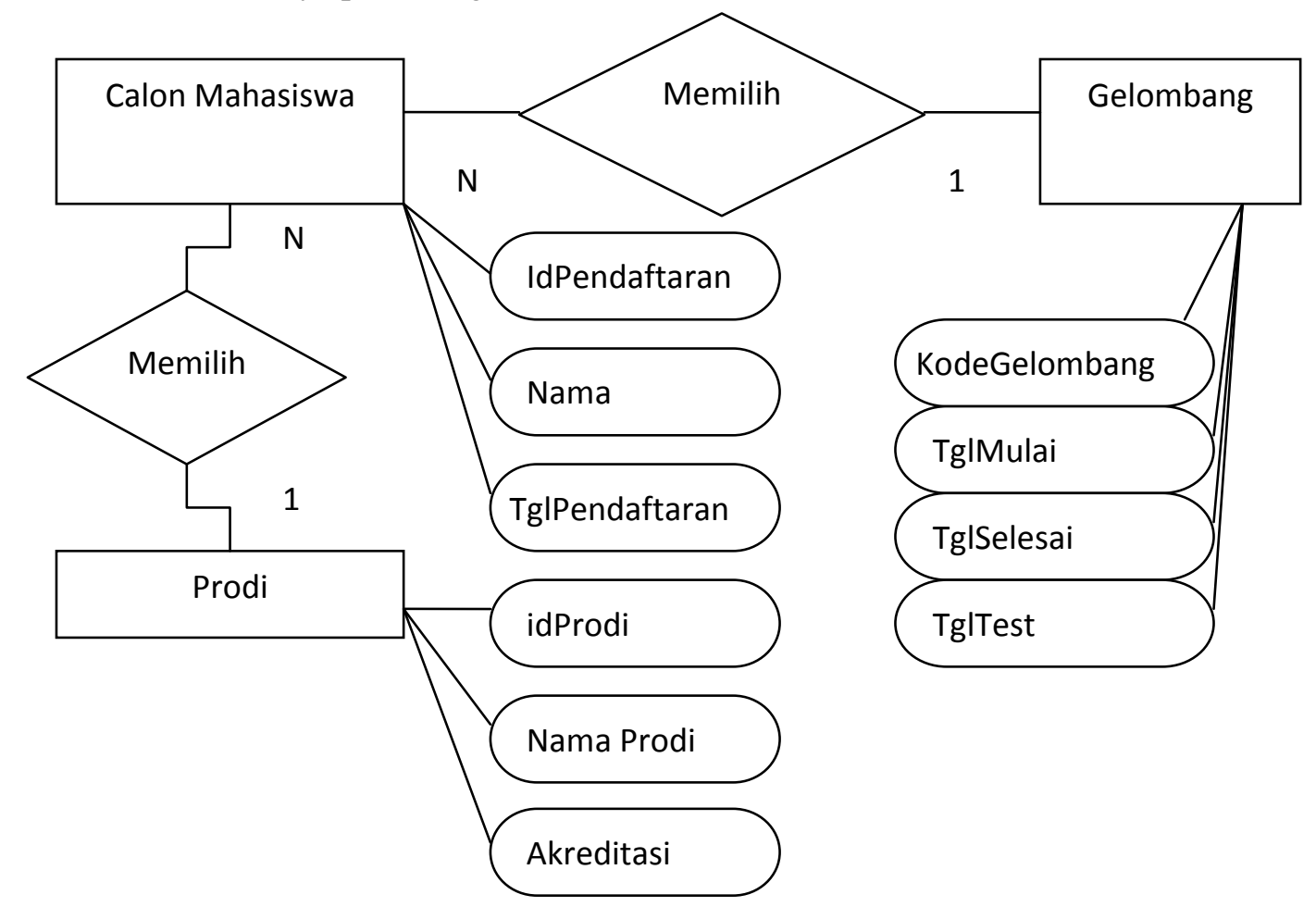

Gambar 4. ER-Diagram

Berdasarkan Gambar 4 terlihat bahwa hubungan antara Gelombang dengan Calon Mahasiswa adalah One to Many, artinya satu gelombang pendaftaran akan diikuti atau dipilih oleh banyak calon mahasiswa. Hubungan antara Prodi dengan Calon Mahasiswa juga One to Many, artinya satu Prodi akan dipilih oleh banyak calon mahasiswa.

\subsubsection{Perancangan Struktur Tabel}

Tabel yang diperlukan dalam merancang basis data meliputi beberapa tabel yang berhubungan dengan proses penerimaan mahasiswa baru meliputi: (1) Tabel program studi, berfungsi untuk menampung data program studi yang dimiliki oleh ASMI Santa Maria Yogyakarta. (2) Tabel Gelombang, berguna untuk mencatat data gelombang pendaftaran mahasiswa baru. (3) Tabel inbox, berguna untuk mencatat pesan SMS yang masuk baik pesan SMS yang benar maupun yang salah. Tabel ini bersifat tabel Log yang hanya untuk menerima pesan SMS apapun yang masuk. Setiap SMS yang masuk perlu dibalas untuk konfirmasi bahwa 
SMS telah diterima dan direspon, untuk itu diperlukan tabel out box. (4) Tabel outbox, berfungsi untuk menampung data calon mahasiswa yang telah diberi balasan SMS dan sudah dipastikan format data SMSnya benar. Tabel ini menjadi tabel data pendaftar melalui SMS yang diproses menjadi laporan.

Relasi antar tabel menunjukkan hubungan relasional dan merupakan hasil proses normalisasi. Tabel Program studi berhubungan dengan tabel outbox dalam aturan one to many. Tabel Gelombang juga berhubungan dengan tabel outbox dalam aturan one to many. Tabel Inbox tidak terhubung dengan tabel lainnya karena hanya berfungsi sebagai penampung SMS masuk.

\subsection{Perancangan Antarmuka Sistem}

\subsubsection{Perancangan Tampilan Awal}

Tampilan awal berisi judul program yang menggunakan metode splash screen untuk menunggu agar program masuk ke tampilan awal program. Gambar 5 adalah rancangan tampilan awal.

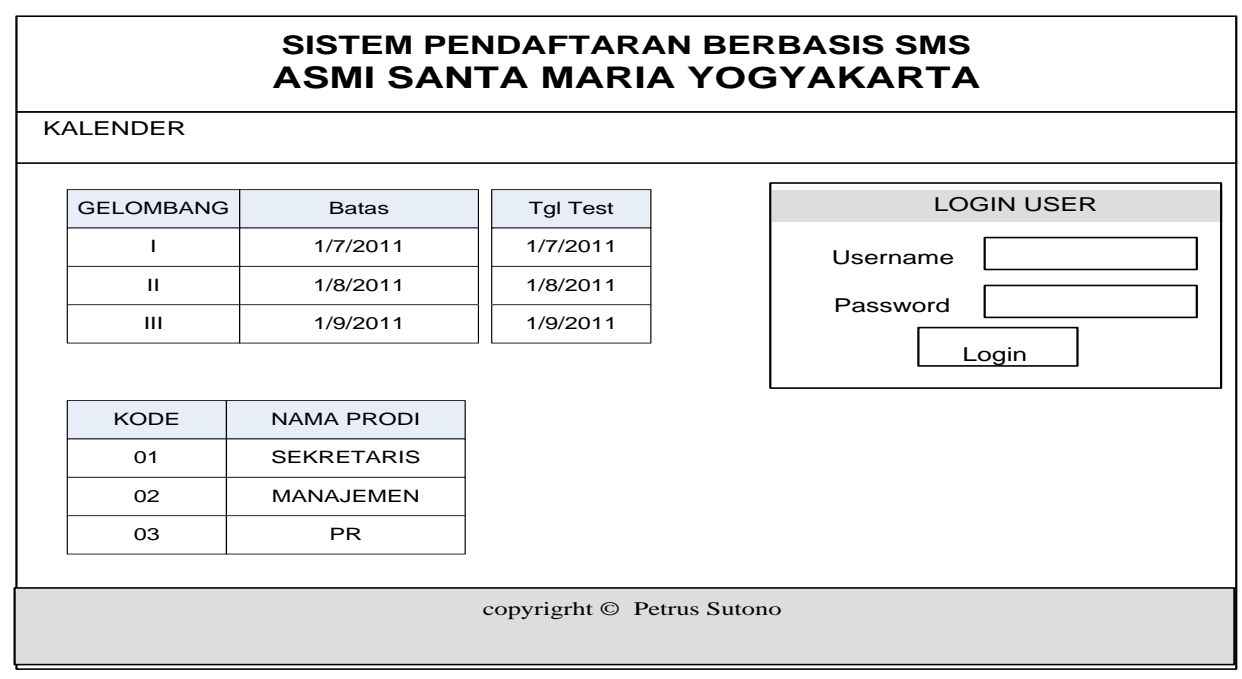

Gambar 5. Rancangan Tampilan Awal

Gambar 5 berguna untuk pengelolaan data gelombang pendaftaran. Penambahan data dilakukan pada isian di bagian bawah. Kemudian klik tombol simpan. Edit data dilakukan dengan klik tombol edit pada data yang dipilih. Untuk hapus data dilakukan klik tombol hapus pada data yang hendak dihapus. Data gelombang pendaftaran akan dipakai dalam menentukan jadwal ujian tes masuk.

Halaman di bawah berguna untuk pengelolaan data Program studi (prodi) yang hendak dipilih. Penambahan data dilakukan pada isian di bagian bawah. Kemudian klik tombol simpan. Edit data dilakukan dengan klik tombol edit pada data yang dipilih. Untuk hapus data dilakukan klik tombol hapus pada data yang hendak dihapus. Data prodi akan dipakai dalam menentukan jumlah peminat per prodi.

\subsubsection{Perancangan Tampilan Untuk Administrator}

Tampilan Utama merupakan menu pull down yang terdiri dari menu Master, Kelola Inbox, Laporan, Home dan Log Out. Gambar 6. berguna untuk mengelola data master dalam sistem pengiriman pesan. Data master adalah data gelombang pendaftaran, data prodi, data calon mahasiswa baru dan data user administrator. Menu kelola inbox berguna untuk mengetahui SMS yang masuk. Menu laporan berguna untuk membuat laporan yang terdiri atas 
laporan pendaftaran dan laporan rekap pendaftaran melalui SMS. Menu Home adalah menuju halaman utama. Menu Log out adalah keluar dari sistem.

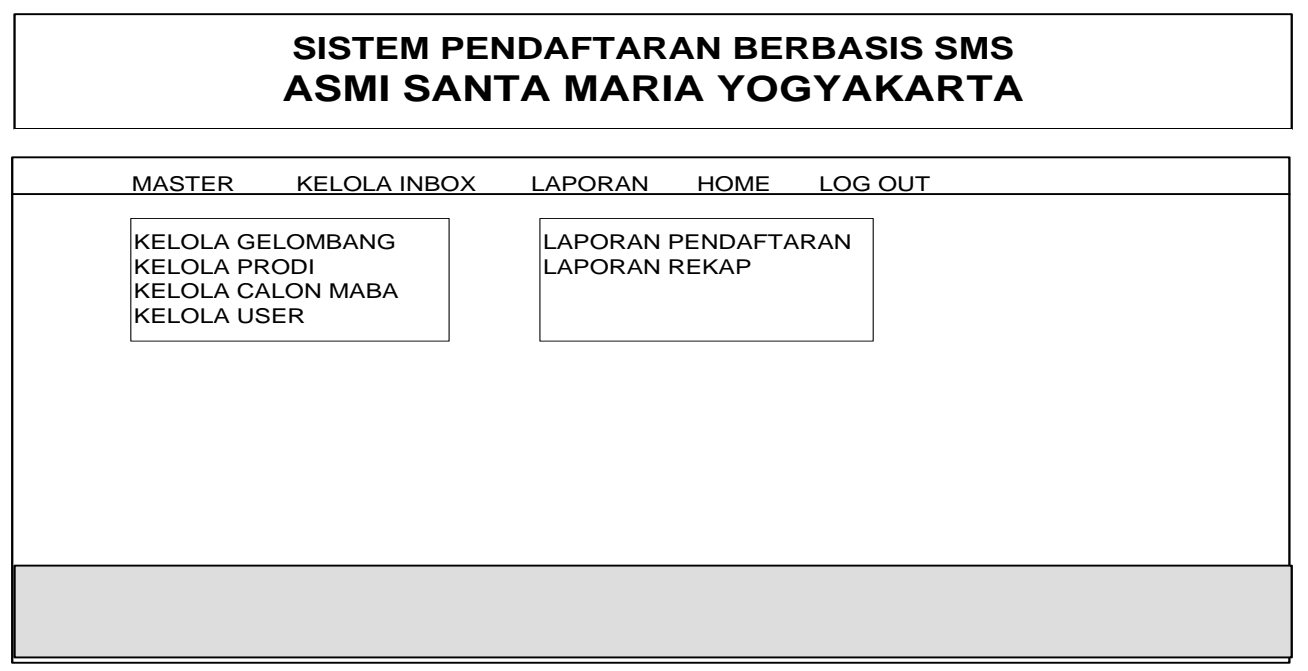

Gambar 6. Rancangan Tampilan Menu Utama Administrator

Gambar 7 berguna untuk pengelolaan data gelombang pendaftaran. Penambahan data dilakukan pada isian di bagian bawah. Kemudian klik tombol simpan. Edit data dilakukan dengan klik tombol edit pada data yang dipilih. Untuk hapus data dilakukan klik tombol hapus pada data yang hendak dihapus. Data gelombang pendaftaran akan dipakai dalam menentukan jadwal ujian test masuk.

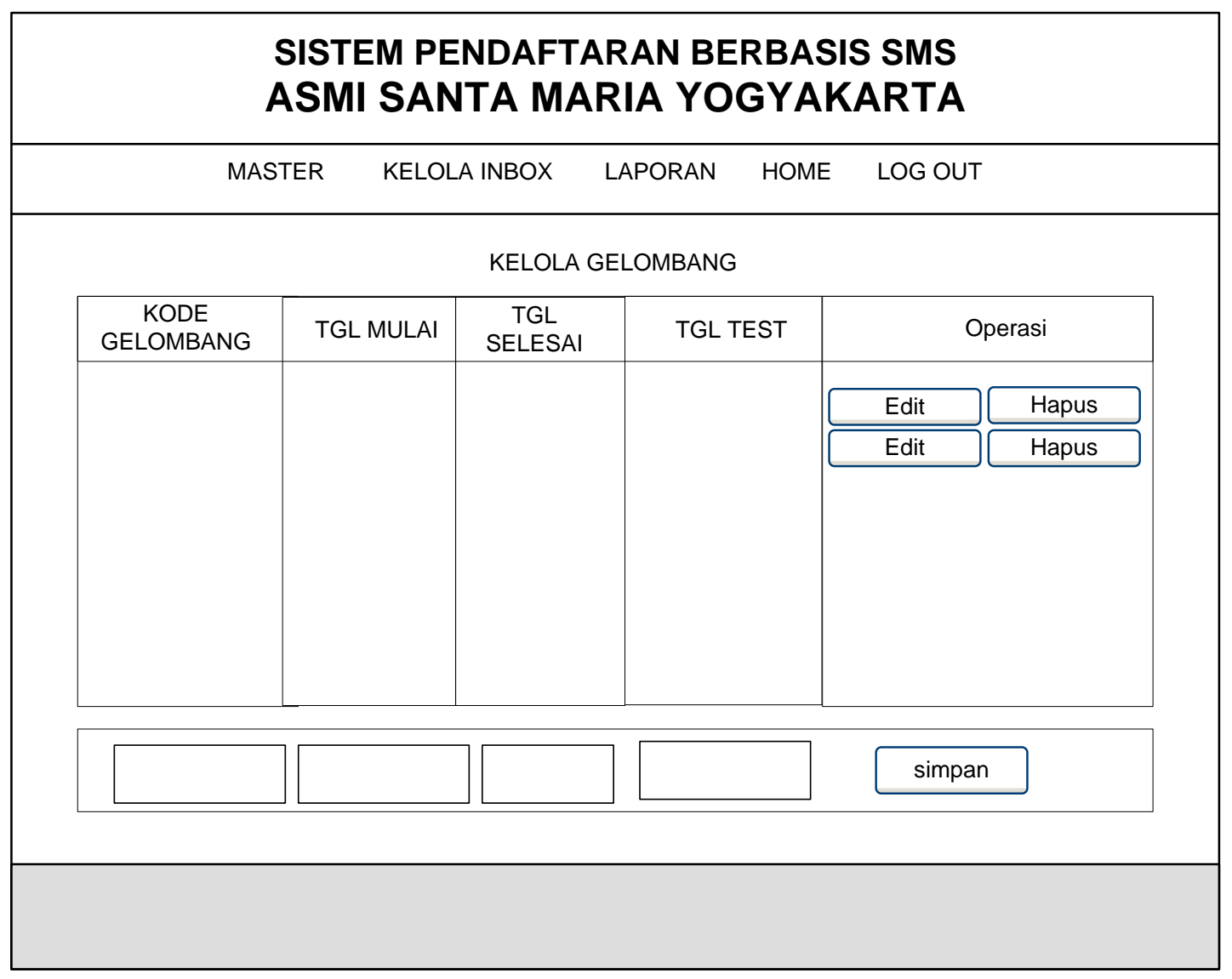

Gambar 7. Rancangan Tampilan Sub Menu Kelola Gelombang 


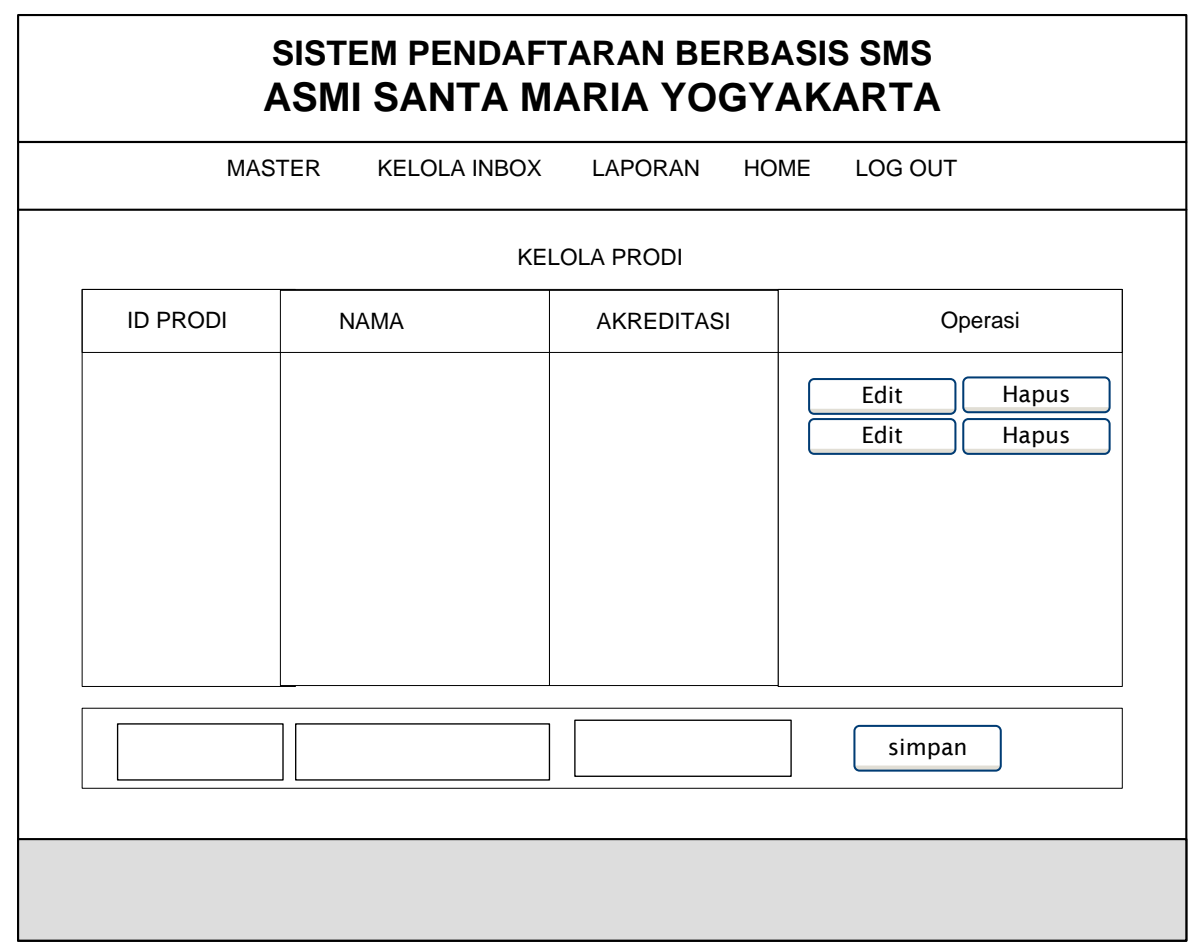

Gambar 8. Rancangan Tampilan Sub Menu Kelola Program studi

Gambar 8 berguna untuk pengelolaan data prodi yang hendak dipilih. Penambahan data dilakukan pada isian di bagian bawah. Kemudian klik tombol simpan. Edit data dilakukan dengan klik tombol edit pada data yang dipilih. Untuk hapus data dilakukan klik tombol hapus pada data yang hendak dihapus. Data prodi dipakai dalam menentukan jumlah peminat per prodi.

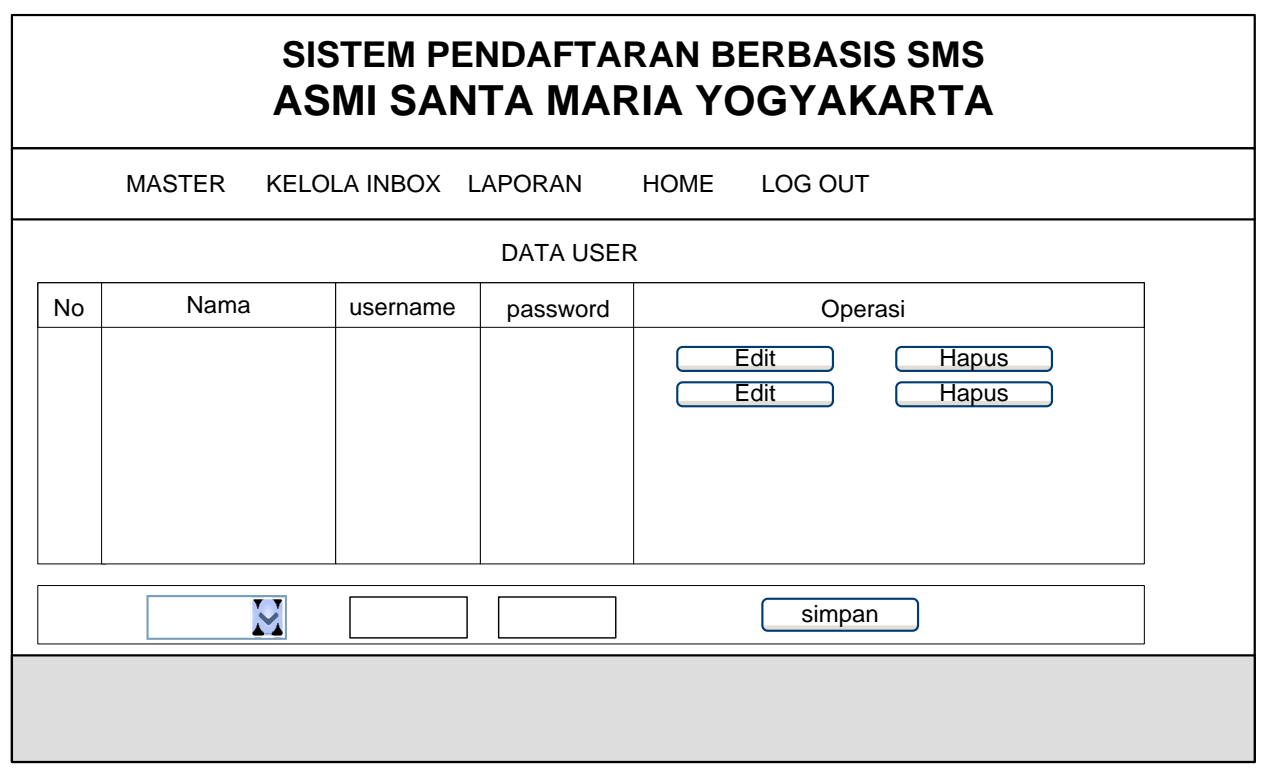

Gambar 9. Rancangan Tampilan Sub Menu Kelola Data User

Gambar 9 berguna untuk pengelolaan data user pengelola sistem. Penambahan data dilakukan pada isian di bagian bawah. Kemudian klik tombol simpan. Edit data dilakukan dengan klik tombol edit pada data yang dipilih. Untuk hapus data dilakukan klik tombol hapus pada data yang hendak dihapus. Data user akan dipakai dalam proses login sistem. 


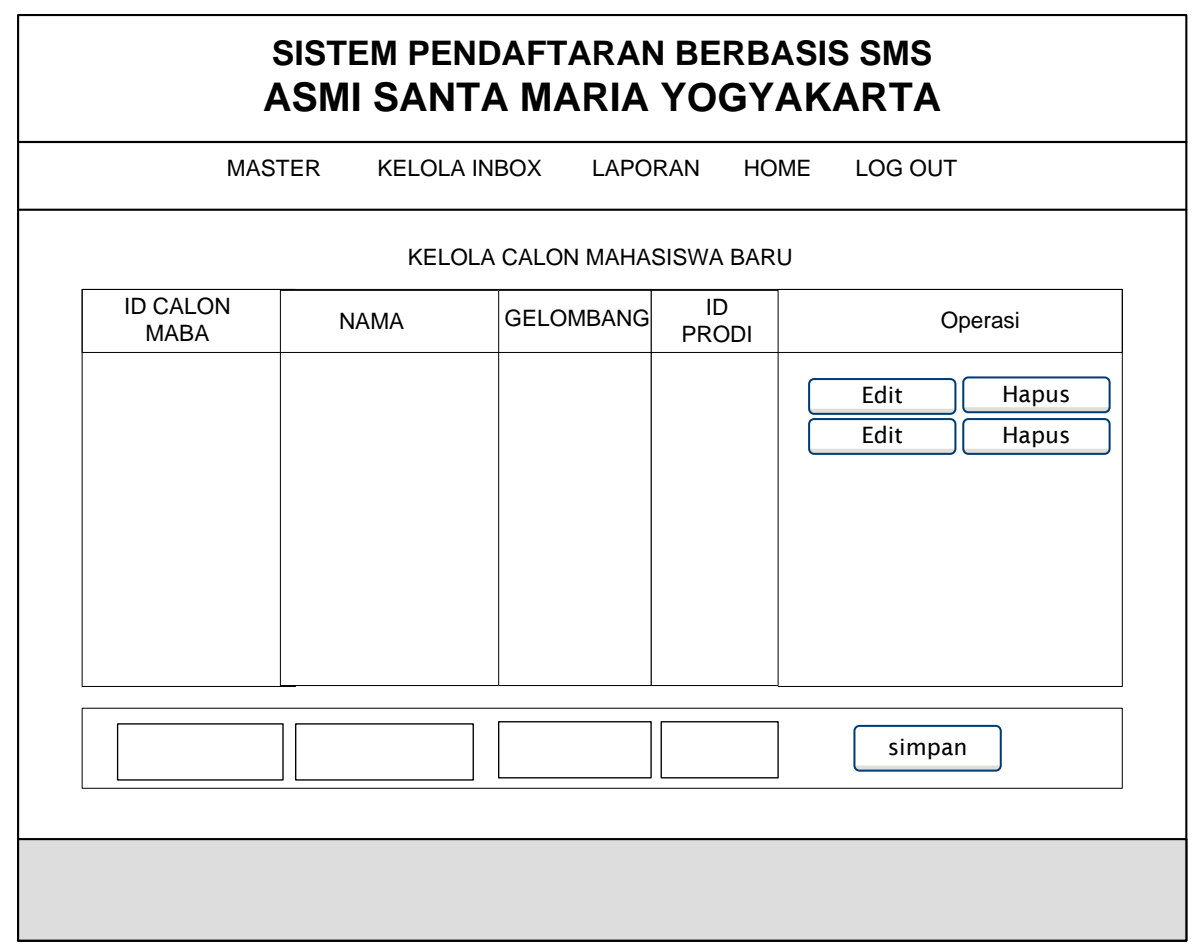

Gambar 10. Rancangan Tampilan Sub Menu Kelola Calon Mahasiswa Baru

Gambar 10 berguna untuk pengelolaan data calon mahasiswa baru yang mendaftar melalui SMS. Data tersebut dapat ditambah, edit dan hapus secara manual tanpa melalui SMS. Penambahan data dilakukan pada isian di bagian bawah. Kemudian klik tombol simpan. Edit data dilakukan dengan klik tombol edit pada data yang dipilih. Untuk hapus data dilakukan klik tombol hapus pada data yang hendak dihapus. Data calon mahasiswa baru melalui SMS akan dilaporkan kepada pimpinan.

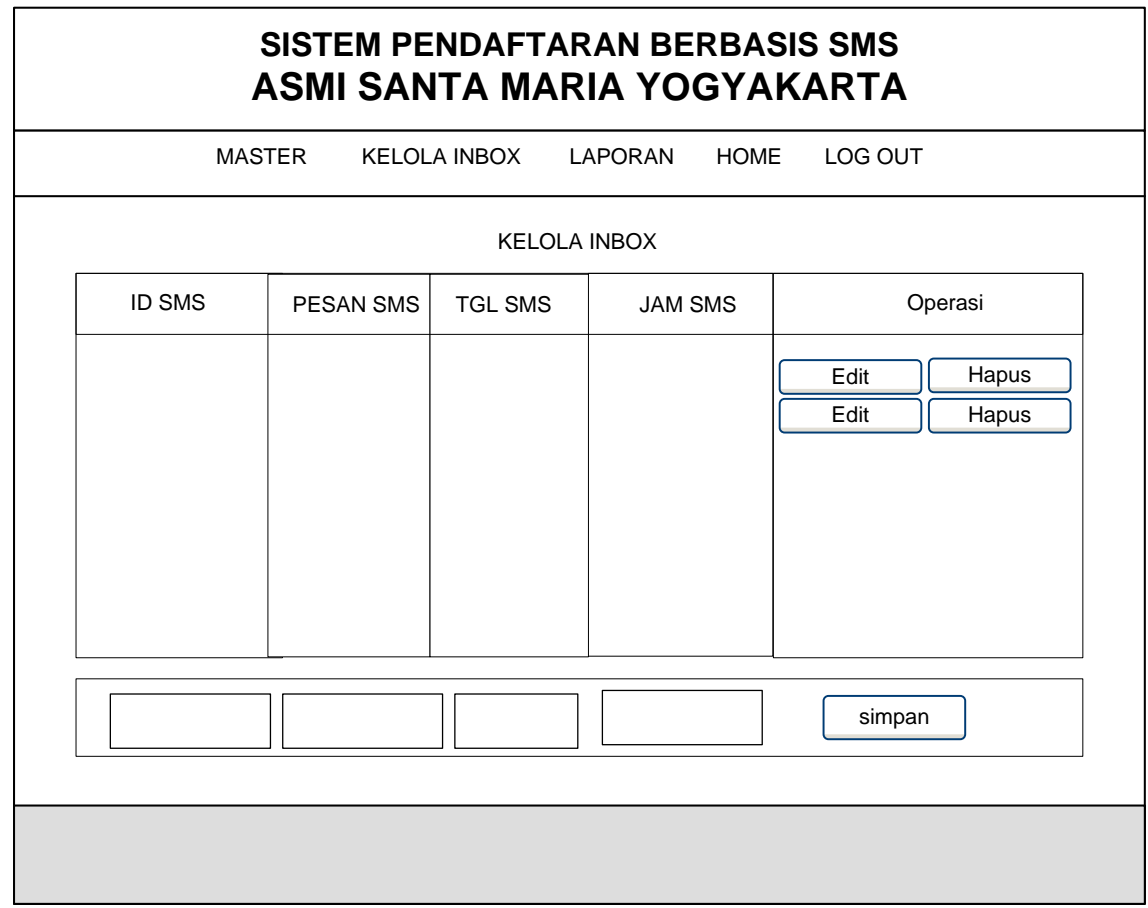

Gambar 11. Rancangan Tampilan Sub Menu Kelola Inbox 
Gambar 11 berguna untuk pengelolaan data inbox berisi semua SMS yang masuk. Administrator dapat melakukan penambahan data, edit dan hapus data inbox secara manual. Penambahan data dilakukan pada isian di bagian bawah. Kemudian klik tombol simpan. Edit data dilakukan dengan klik tombol edit pada data yang dipilih. Untuk hapus data dilakukan klik tombol hapus pada data yang hendak dihapus. Data inbox dapat dipakai untuk mengetahui jumlah seluruh SMS yang masuk baik SMS yang dapat diproses maupun tidak dapat diproses.

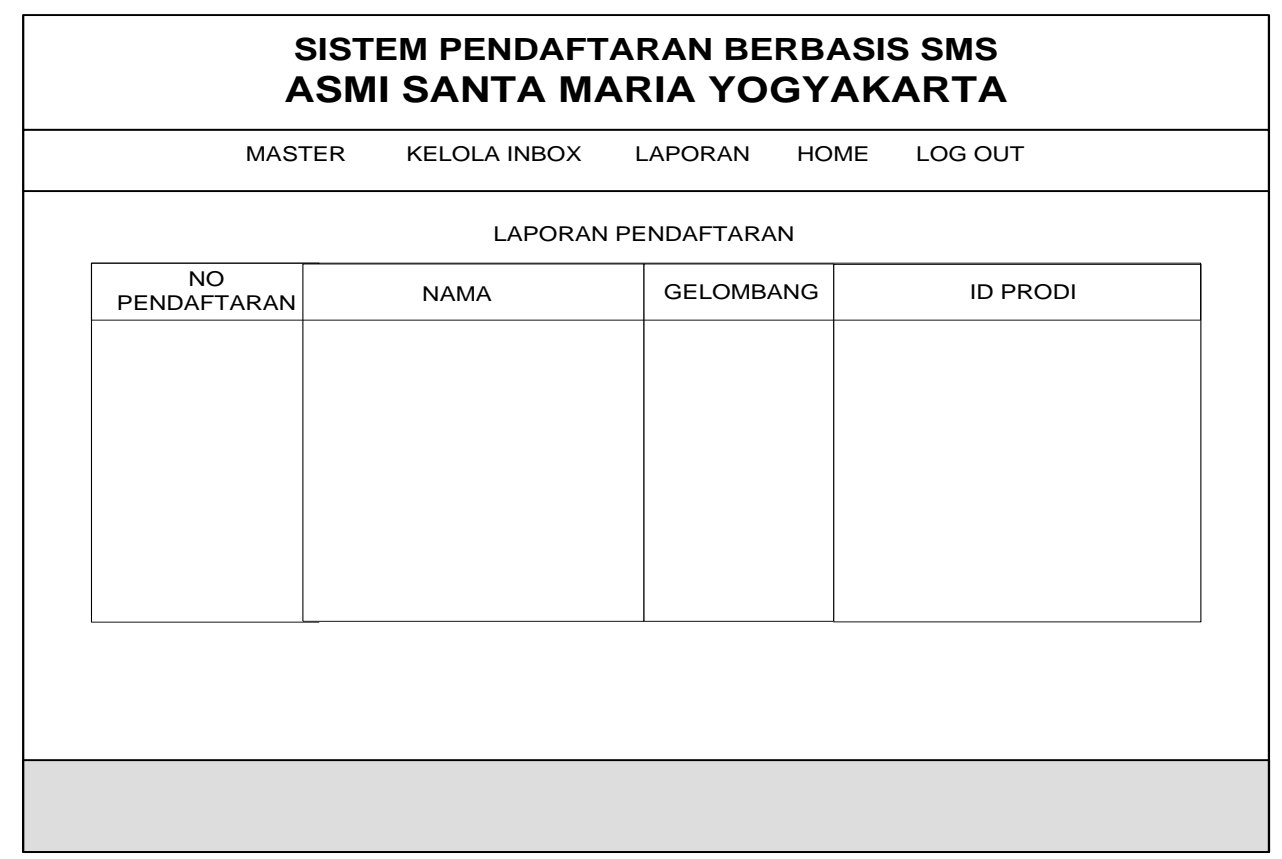

Gambar 12. Rancangan Tampilan Sub Menu Laporan Pendaftaran Melalui SMS

Gambar 12 berguna untuk pelaporan data pendaftaran. Laporan berbentuk tabel yang akan menginformasikan nomor pendaftaran, nama, gelombang pendaftaran dan prodi yang diminati. Laporan ini dapat dipakai sebagai informasi jumlah pendaftar melalui sarana SMS. Laporan juga dapat dipakai untuk melengkapi data pendaftaran tanpa melalui SMS atau untuk membuat absensi test khusus pendaftar melalui SMS.

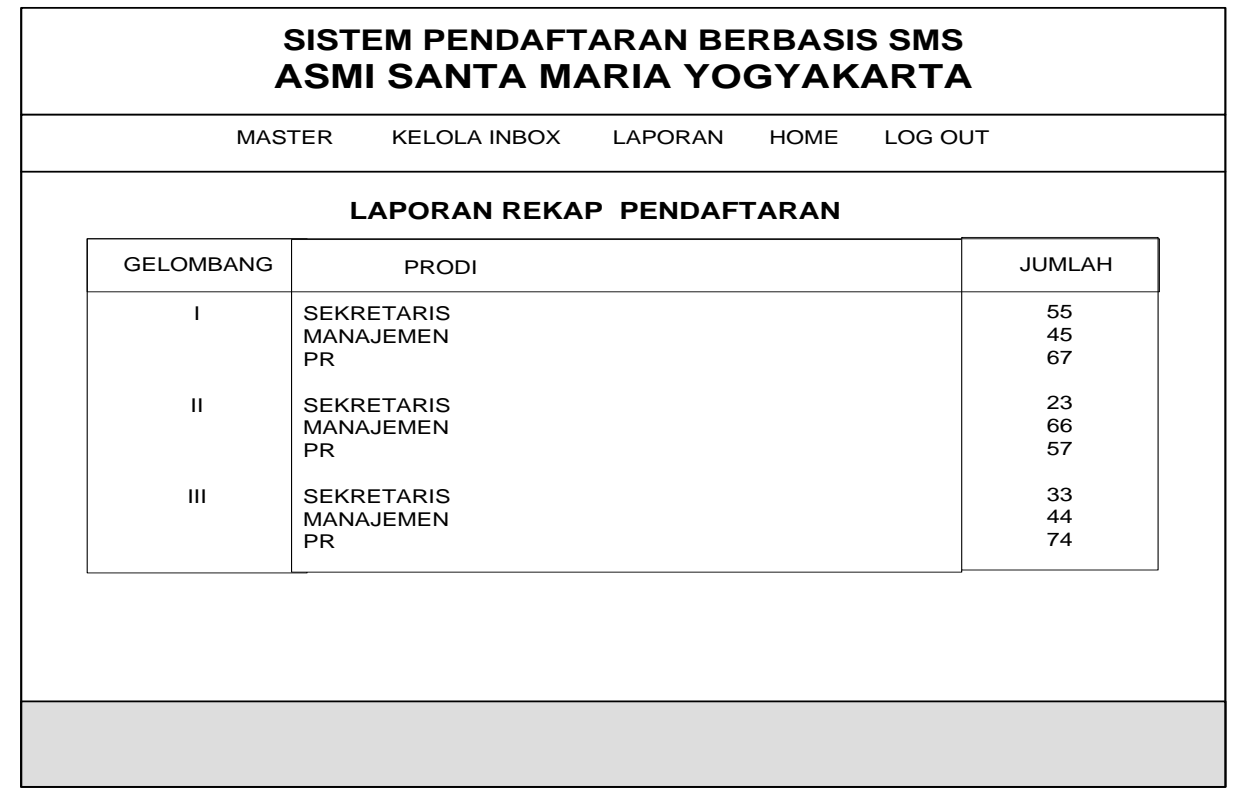


Gambar 13. Rancangan Tampilan Sub Menu Laporan Rekap Pendaftaran melalui SMS

Gambar 13 berguna untuk pelaporan rekap data pendaftaran. Laporan berbentuk tabel yang akan menginformasikan jumlah pendaftar pe program studi bagi semua program studi yang ada. Laporan ini dapat dipakai sebagai informasi jumlah pendaftar melalui sarana SMS per program studi. Laporan juga dapat dipakai untuk mengetahui minat masyarakat untuk mendaftar melalui sarana SMS.

\subsection{Perancangan Antarmuka Telepon Seluler (Handphone)}

Bentuk pesan SMS yang dikirim dari calon mahasiswa kepada sistem mengikuti format aturan yang telah baku dan ditentukan oleh manajemen penerimaan mahasiswa baru. Bentuk format yang dipakai adalah sebagai berikut:

\section{REG (spasi) IDPRODI (spasi) GELOMBANG (spasi) NAMA}

Contoh: REG 011 Haris Sarbini artinya Haris Sarbini akan mendaftar di Prodi 01 yaitu Sekretaris dan gelombang 1. Maka pengiriman melalui telepon seluler akan memiliki bentuk antarmuka seperti terlihat pada gambar 14.

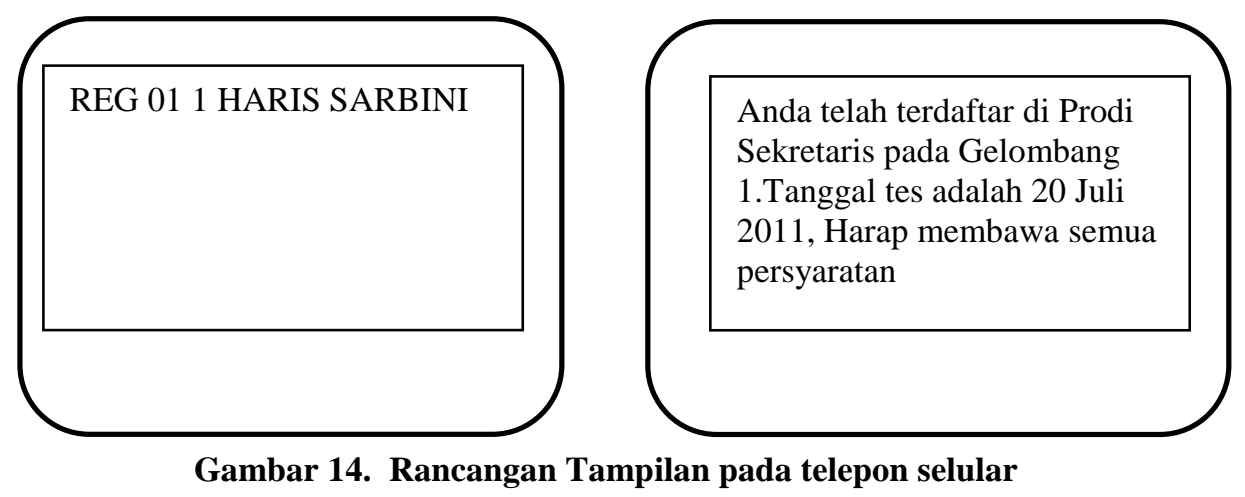

Gambar 14. menunjukkan proses pendaftaran mahasiswa baru melalui SMS, jika sukses maka akan mendapatkan balasan sebagai berikut : "Anda telah terdaftar di Prodi Sekretaris pada Gelombang 1.Tanggal tes adalah 20 Juli 2011, Harap hadir membawa semua persyaratan pendaftaran sebagai syarat mengikuti tes"

JIka pendaftaran tidak sukses, mungkin karena salah format SMS atau karena prodi dan gelombang tidak ada atau sudah terlambat, maka format pesan balasan adalah salah satu dari beberapa format berikut:

"Anda salah menuliskan format pesan SMS"

"Anda terlambat mengikuti gelombang tersebut"

"Anda salah kode program studi dipilih"

\section{Kesimpulan}

Kesimpulan yang didapatkan dari penelitian ini adalah aplikasi pendaftaran mahasiswa baru berbasis SMS pada ASMI Santa Maria Yogyakarta telah berhasil didesain dengan pendekatan terstruktur.

\section{Saran}

Aplikasi pendaftaran mahasiswa baru ini dirancang memberikan informasi mengenai data pendaftar yang masuk melalui SMS, selanjutnya dapat dikembangkan secara lengkap dengan memasukkan; kalkulasi nilai tes, beban biaya studi yang meliputi Biaya Operasi 
Pendidikan (BOP) dan SPP yang harus ditanggung oleh pendaftar yang bersangkutan.

\section{Referensi}

Alan Dennis, Barbara Haley Wixom, David Tagarden. Systems Analysis \& Design: An ObjectOriented Approach with UML. John Wiley \& Son. USA. 2002.

Anonymous. "Dynmark International: SMS is Most Effective Communication Channel During Emergency”. Wireless News Publication. Sep 142010. (http://proquest.umi.com/pqdweb)

April Richardson, Ofelia M. Littrell, Sandra Challman, Pamela Stein, "Using Text Messaging in an Undergraduate Nursing Course". Journal of Nursing Education. Thorofare: Feb 2011. Vol. 50, Iss. 2; pg. 99, 6 pgs. http://proquest.umi.com/pqdweb.

Aryani, Siti Nur, SMS dan Dinamika Komunikasi Massa, Tabloid Trendigital http://www.trendigital.com terbitan tanggal 03-01-2006

Budi Sutedjo Dharma Oetomo \& Handoko, Yosia.Teleakses Database Pendidikan Berbasis Ponsel. Penerbit Andi. Yogyakarta. 2003

Carol Britton \& Jill Doake.Object Oriented Systems Development: A Gentle Introduction. Mc. Graw Hill. 2001.

Firmansyah, Arif , GAMMU and SQLServer, Artikel Universitas Padjajaran, http://arif.unpad.ac.id/?p=31 terbit tanggal 26 Maret 2008

George M. Marokas. Systems Analysis and Design: An Active Approach.Prentice Hall.Uper Sadlle River, New Jersey. 2006.

Henry C. Lucas JR. Penerjemah Abdul Basith. Analisis Desain dan Implementasi Sistem Informasi. Penerbit Erlangga. 1993.

Igor Hawryszkiewycz. System Analysis \& Design.Fifth Edition.Prentice Hall. 2001.

Jeffrey L. Whitten, Lonnie D. Bentley, Kevin C. Dittman. Systems Analysis and Design Methods.5 th Edition. Mc.Graw Hill. 2001.

Joseph S. Valacich, Joey F. George, Jeffrey A Hoffer. Essentials of Systems Analysis \& Design.Second Edition.Prentice Hall. 2004.

Khang, Ir. Bustam. Trik Pemrograman Aplikasi Berbasis SMS.Elex Media Komputindo. Jakarta, 2002

Ridwan Sanjaya. Kiat-Kiat Menguasai Teknologi Informasi.Penerbit Universitas Atma Jaya Yogyakarta. 2007.

Romzi Imron Rosidi. Membuat Sendiri SMS Gateway(ESME): Berbasis Protokol. Penerbit Andi Yogyakarta 2004.

Sarwati Rahayu, Mahmudi, Perancangan program aplikasi pemesanan barang melalui SMS menggunakan Visual Basic 6.0.Jurnal FIFO (Forum Informasi Fakultas Ilmu Komputer). Universitas Mercu Buana. Vol.I/No.1/Mei/2009.

Simon Bannet, Steve Mc Robh, and Ray Farmer. Object-Oriented Systems.Analysis and Design.Using UML.Mc. Graw Hill. 2002.

Situmorang Alfonsius, 2004, Implementasi SMS Gateway pada Sistem Informasi Akademik Berbasis SMS. Kasus SIA Program Pasca Sarjana Ilmu Komputer UGM, Tesis Program Pasca Sarjana Universitas gadjah Mada Yogyakarta

Tommi Mikkonen. Programming Mobile Device : An Introduction for Practitioners.John Wiley \& Son. USA. 2007.

Utomo, Prasetya Ambang.Membangun Aplikasi SMS Berbasis Open Source, Penerbit Andi.Yogyakarta. 2006. 